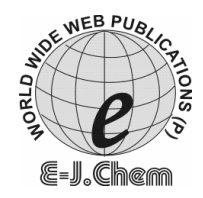

http://www.e-journals.net
ISSN: 0973-4945; CODEN ECJHAO

E-Journal of Chemistry

2009, 6(1), 270-272

\title{
A Solution Study of Complex Formation of Some Diamines with Lanthanones
}

\author{
J.J.VORA*, D.R.PATEL ${ }^{\text {II }}$, ASHA D. PATEL, KANU PATEL ${ }^{\S}$, \\ SANGITA SHARMA, LAXMAN S. BHUTADIYA ${ }^{\#}$ and SUNIL B. VASAVA
}

\author{
Department of Chemistry, \\ Hemchandracharya North Gujarat University, Patan-384 265, Gujarat, India. \\ ${ }^{\text {II } M u n i c i p a l ~ A r t s ~ \& ~ S c i e n c e ~ C o l l e g e, ~ M e h s a n a-384 ~ 002, ~ G u j a r a t, ~ I n d i a . ~}$ \\ ${ }^{\S}$ Shri M.P. Pandya Science College, Lunavada, Gujarat, India.

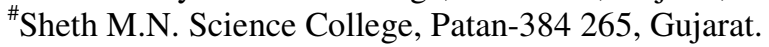 \\ jabali_vora@hotmail.com
}

Received 28 April 2008; Accepted 10 June 2008

\begin{abstract}
To study the metal ligand equilibrium in aqueous solution, the well known Irving-Rossotti titration method was used. The temperature selected is $30 \pm 0.1^{0} \mathrm{C}$ at ionic strength $0.2 \mathrm{M}\left(\mathrm{NaClO}_{4}\right)$ which was maintained constant through out the work. The binary metal complex $\left(\mathrm{ML}_{2}\right)$ formation was studied. The metals selected are $\mathrm{Sm}^{3+}, \mathrm{Gd}^{3+}, \mathrm{Dy}^{3+}$ and $\mathrm{Yb}^{3+}$. The diamine ligands taken are ethylenediamine, 1,2 diamino propane, 1,3 diamino propane, $N-N$ diethyl ethylenediamine and $N$ - $N$-dimethyl ethylenediamine. Factors that affected the stability of the complexes are size and ionic potential of lanthanone ions, basicity of ligands, ring size and steric effect of ligands.
\end{abstract}

Keywords: Lanthanone ions, Diamines, Equilibrium study

\section{Introduction}

The chemistry of lanthanones has been extensively reviewed ${ }^{1,2}$. During last 15 years, the lanthanone(III) complexes have been extensively used for medical diagnostic methods like MRI (magnetic resonance imaging) $)^{3,4}$. Complexes of lanthanones in solid state were studied for their photo chemical and thermal properties ${ }^{5}$. Lanthanones have been employed as aids to the separation, preparation and purification of molecular cells in immunoassay in histochemistry ${ }^{6}$. Complexes of lanthanones with nitrogen donor ligands of weak basicity are well known ${ }^{7,8}$. Europium complexes with 1,10-phenanthroline were studied for their formation, bonding characteristics and important photochemical properties ${ }^{9}$. Amino acids are well known chelating agents, their importance in biological system and in industry has earned attention of chemists for their metal complexes ${ }^{10-13}$. During past several decades, diamines and their derivatives are studied for important applications as stable complexes in fields like biotechnology, environmental science and biochemistry, etc $^{1416}$. 
In the present study, an attempt has been made to determine the stability constants of binary complexes of $\mathrm{Sm}(\mathrm{III}), \mathrm{Gd}(\mathrm{III}), \mathrm{Dy}(\mathrm{III})$ and $\mathrm{Yb}(\mathrm{III})$ with some diamines. Various factors influencing the formation and stabilities of binary complexes have been discussed.

\section{Experimental}

All the reagents used were of A.R. grade. Lanthanone trivalent metal nitrates (Aldrich) were used. The amines (E-Merck) perchloric acid (Baker Analyzed), sodium perchlorate (Fluka) and sodium hydroxide (BDH Analar Grade) were used.

All the solutions for the equilibrium study were prepared in conductivity water. Perchloric acid and sodium hydroxide were standardized by acid-base titration ${ }^{17}$, while metal nitrate solutions were standardized by complexometry method ${ }^{18}$. Systronics $\mu \mathrm{pH}$ system 361 with readability \pm 0.01 was used for potentiometric studies. $\mu \mathrm{pH}$ meter was calibrated with buffer solutions and calibration was checked intermittently.

All potentiometric titrations were carried out at $30 \pm 0.01{ }^{\circ} \mathrm{C}$ by using carbon dioxide free sodium hydroxide solution ${ }^{19}$. The proton ligand and metal ligand stability constants are calculated using EXCEL computer program on the basis of literature method ${ }^{20}$.

\section{Result and Discussion}

The formation constants of the binary complexes formed due to interaction of trivalent lanthanone(III) ions with diamines i.e. $N-N$ diethyl ethylenediamine, $N-N$ dimethyl ethylenediamine, 1,3 diamino propane and 1,2 diamino propane were calculated by measuring the magnitude of the shift in $\mathrm{pH}$ observed during the titration of the ligand in absence and in the presence of metal against standard sodium hydroxide solution ${ }^{21}$. The proton ligand and metal ligand stability constants are presented in the Table 1.

Ethylenediamine, 1,2 diaminopropane, 1,3 diaminopropane, $N-N$ diethyl ethylenediamine and $N-N$ dimethyl ethylenediamine are bidentate ligands. The basicity of $N-N$ diethyl ethylenediamine is highest among the diamines used. It is observed that proton ligand stability constant values are of the same order as reported earlier ${ }^{22}$.

Proton ligand stability constants are in the following order.....N-N diethyl ethylenediamine > $N-N$ dimethyl ethylenediamine $>1,2$ diamino propane $>$ ethylenediamine $>1,3$ diamino propane.

Metal ligand stability constant value for $N-N$ dimethyl ethylenediamine are higher than $N-N$ diethylethylenediamine although proton ligand stability constant for $N-N$ diethyl ethylenediamine is higher than $N-N$ dimethyl ethylenediamine. The steric hinderance due to present of two $-\mathrm{C}_{2} \mathrm{H}_{5}$ groups on two chelating nitrogen atoms of $N-N$ diethyl ethylenediamine has lowered the value of binary stability constants of $\mathrm{M}(\mathrm{III}) \mathrm{N}-\mathrm{N}$ diethylethylenediamine than $\mathrm{M}(\mathrm{III}) \mathrm{N}-\mathrm{N}$ dimethyl ethylenediamine.

Besides the basicity of the ligand, size of metal ion and charge/size ratio also plays an important role in determining the value of metal ligand stability constant. Lanthanones(III) form stable complexes and the order of the stability are expected ${ }^{23}$ with respect to the electronic configuration, size and ionic potential of tripositive ions. In present study, this order is followed by $\log \mathrm{K}_{1}$ values for Gadolium and Dysprosium complexes as expected with respect to ligand basicity. In other cases, there is deviation in order of metal ligand stability constants. This may be due to combined effect of steric factor, size of lanthanone ion and charge/size ratio of lanthanone ion $^{24}$. 
Table 1. Proton-ligand and metal-ligand stability constants of lanthanone(III) ions at temperature $30 \pm 0.1^{0} \mathrm{C}$. Ionic strength $\mu=0.2 \mathrm{M} \mathrm{dm}^{-3}\left(\mathrm{NaClO}_{4}\right)$.

\begin{tabular}{|c|c|c|c|c|c|c|}
\hline Metal Ligand & $\mathrm{pk}_{1}{ }^{\mathrm{H}}$ & $\mathrm{pk}_{2}{ }^{\mathrm{H}}$ & $\begin{array}{c}\mathrm{Sm} \\
\log \mathrm{k}_{1} \log \mathrm{k}_{2}\end{array}$ & $\begin{array}{c}\mathrm{Gd} \\
\log \mathrm{k}_{1} \log \mathrm{k}_{2}\end{array}$ & $\begin{array}{c}\text { Dy } \\
\log k_{1} \log k_{2}\end{array}$ & $\begin{array}{c}\mathrm{Yb} \\
\log \mathrm{k}_{1} \log \mathrm{k}_{2}\end{array}$ \\
\hline Ethylene diamine & 9.77 & 7.04 & $4.44 \quad 3.54$ & 4.223 .84 & 4.123 .38 & 4.563 .49 \\
\hline 1,2 diamino propane & 9.85 & 6.97 & 4.683 .67 & 4.444 .10 & $4.64 \quad 4.05$ & 4.703 .67 \\
\hline 1,3 diamino propane & 9.56 & 8.19 & 4.223 .69 & 4.593 .51 & 5.003 .79 & 4.233 .63 \\
\hline $\begin{array}{l}N-N \text { diethyl } \\
\text { ethylene diamine }\end{array}$ & 10.51 & 7.09 & $4.33 \quad 3.54$ & 4.684 .21 & $5.06 \quad 4.66$ & 5.254 .69 \\
\hline $\begin{array}{l}N-N \text { dimethyl } \\
\text { ethylene diamine }\end{array}$ & 9.89 & 6.73 & 5.053 .87 & 5.684 .54 & 5.994 .76 & 5.654 .72 \\
\hline
\end{tabular}

\section{Conclusion}

All the diamines selected were found to form complexes in solution state under the experimental conditions. Their order of stabilities is explained on the basis of basic character of ligands, size of metal ion, steric effects etc. The study also suggests the possibility of the formation of complexes in solid state.

\section{References}

1. Morris L R, Chem Rev., 1976, 76, 827-841.

2. Mellor T, Martin D E, Thompson L C, Ferrus R, Feister F R and Randiate W J, Chem Rev., 1965, 65, 1-50.

3. Aime S, Crich S G, Gianolio E, Giovenzana G B, Tei L and Terreno E, Coordination Chem Rev., 2006, 250(11-12),1562-1579.

4. Picard C, Geum N and Nasso I., Bioorg Med Chem Lett., 2006, 16(20), 5309-5312.

5. Fernandes A, Jaud J, Dexpert-Ghys J and Brouca-Cabarrecq C, Polyhedron., 2001, 18(20), 2385-2391.

6. Evans C H, Biochemistry of The Lanthanides, Plenum Press, New York, 1990, 76.

7. Hart F A and Laming F P, Proc Chem Soc., London, 1963,107.

8. Lobanov N I and Smirnovg V A, Zh Neorg Khim., 1963, 8, 2206.

9. Lianshe Fua, Ferreiraa R A, Nobrea S S, Carlosa L D, and Rochac J, J Luminescence, 2007, 122-123, 265-267.

10. Morrison R T and Boyd R N, Organic Chemistry; $4^{\text {th }}$ Ed., Ellyn and Bacon Inc: London., 1959, 1118.

11. Stack W F and Skinner H A, Trans Faaraday Soc., 1967, 63, 1136.

12. Beech G Q, Chem Rev., 1970, 23, 410.

13. Jain, Alok K, Khan and Frid, J Indian Council Chemists, 1996, 13(2), 42.

14. Barbucci R, Magnani A and Leone G, Polymer, 2002, 43, 3541.

15. Sebela M, Frebort I, Lemr K, Brauner F and Pec P, Arch Biochem Biophys., 2000, 384, 88.

16. Bouchereau A, Aziz A, Larher F and Martin-Tanguy J, Plant Sci.,1999, 140,103.

17. Vogel A I., Text Book of Quantitative Inorganic Analysis; $4^{\text {th }}$ Ed., Longman, 1978, 296.

18. Brunisholz G. and Cohen R., Helv Chim Acta, 1956, 39, 324; ibid., 1956, 39, 2136.

19. Mavani I P, Jejurkar C R and Bhattacharya P K, J Indian Chem Soc., 1972, 49, 469.

20. Iriving H M and Rossotti H S, JIndian Chem Soc., 1954, 2904.

21. Patel V M, Sharma S S, Vora J J and Joshi J D, J Indian Council Chemists, 1997, 13(1), 16.

22. John, Dean A, Lange's Hand Book of Chemistry; $13^{\text {th }}$ Ed., Mcgraw Hill, 1987, 5-38.

23. Patel A D and Joshi J D., J Indian Council Chemists, 1993, 9(2), 683.

24. Pabreja D S, Patel R A, Sharma S S, Vora J J and Joshi J D, Asian J Chem., 2001, 13(1), 357. 


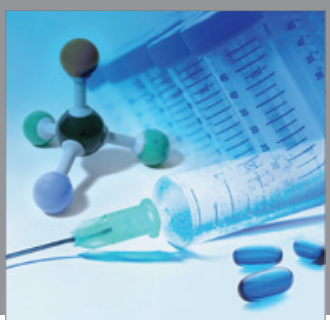

International Journal of

Medicinal Chemistry

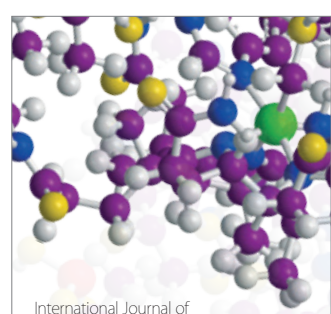

Carbohydrate Chemistry

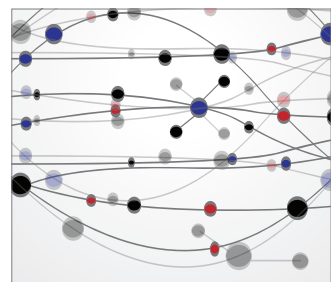

The Scientific World Journal
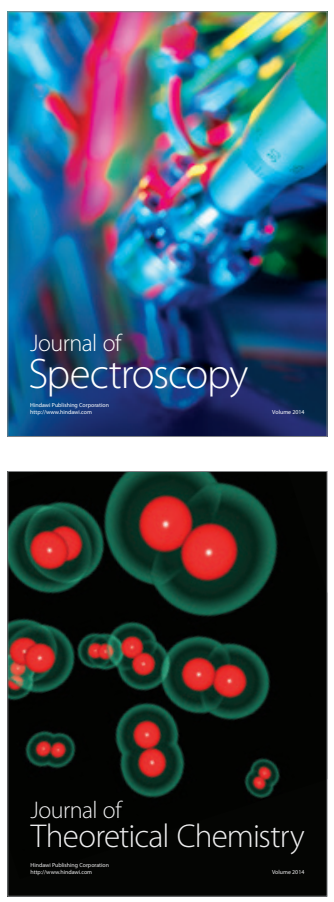
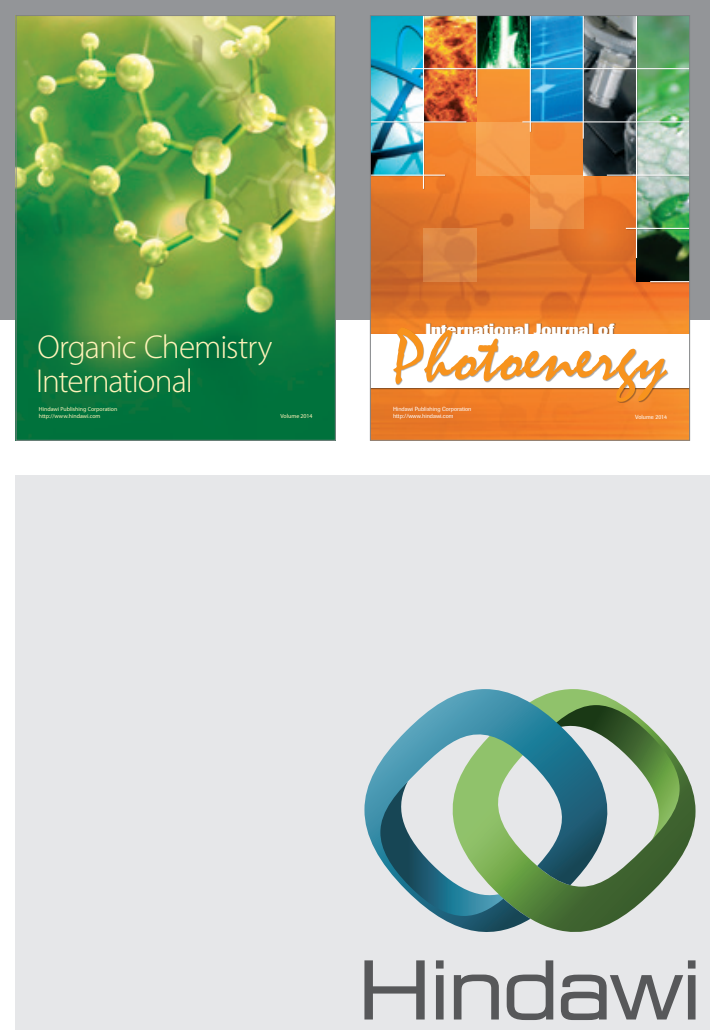

Submit your manuscripts at

http://www.hindawi.com
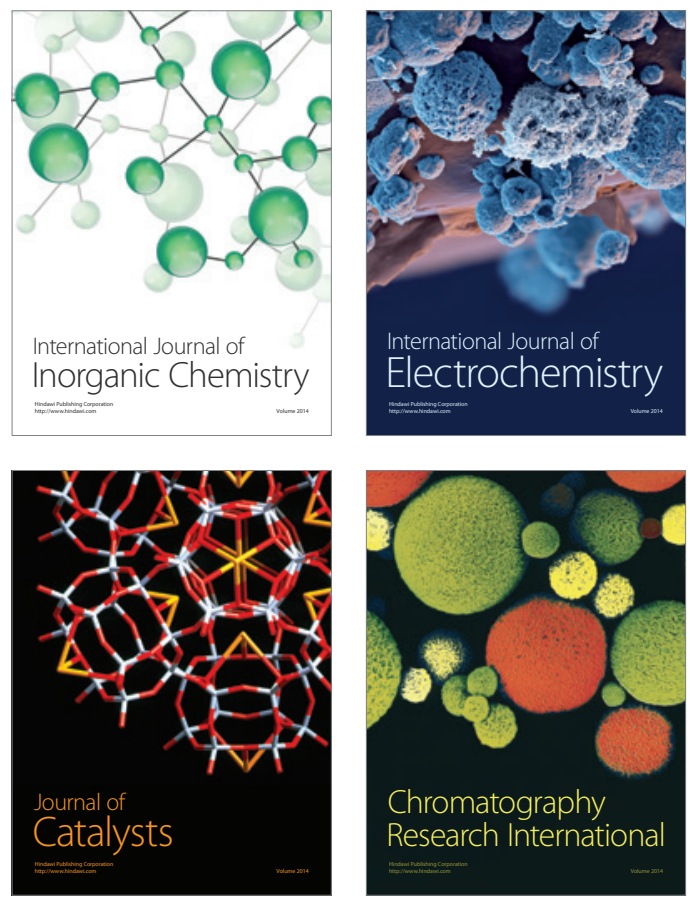
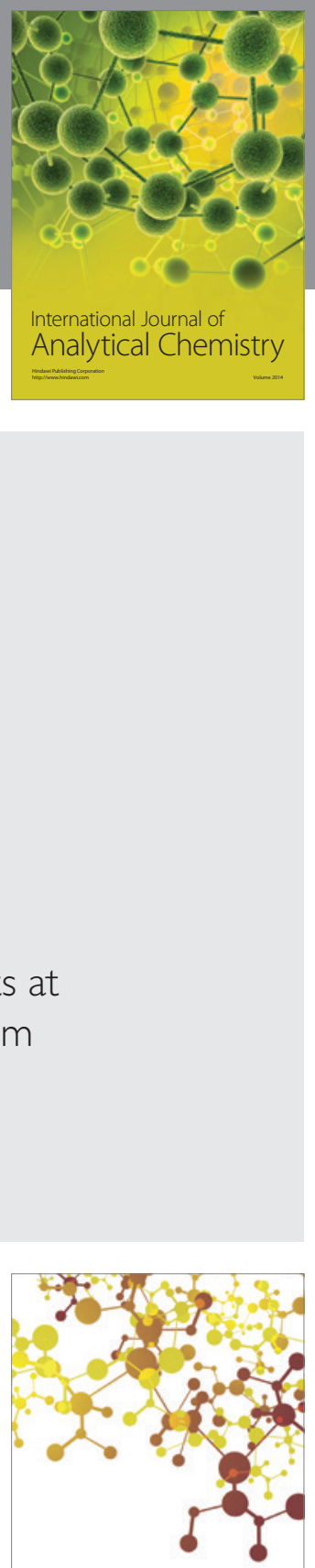

Journal of

Applied Chemistry
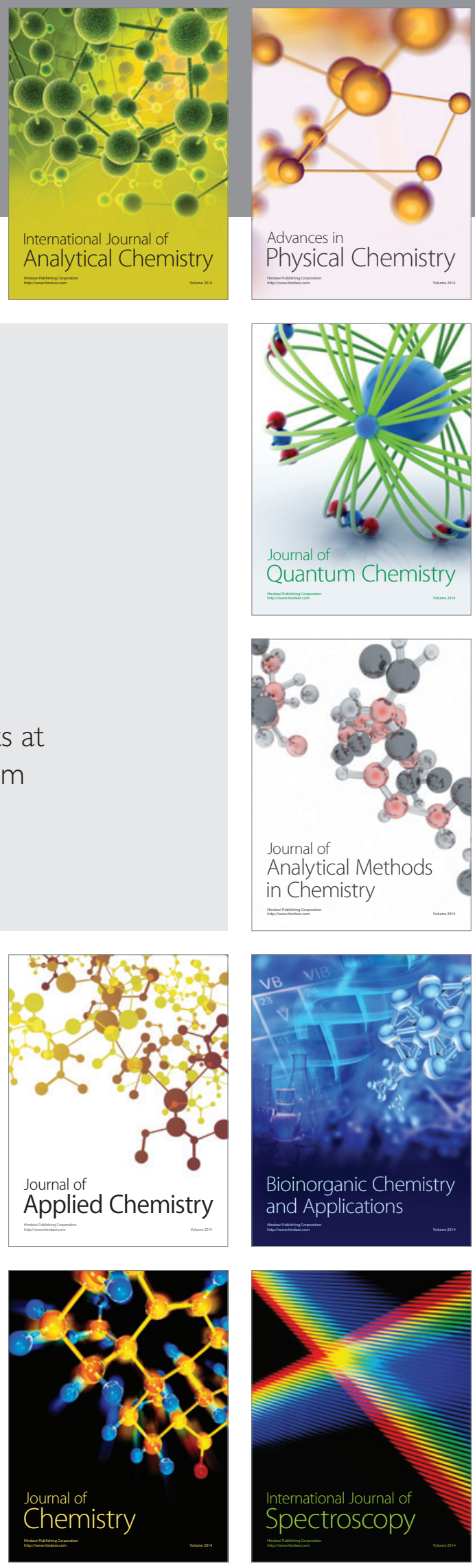